\title{
Adiponectin, Diabetes and Coronary Artery Disease
}

\author{
Dhastagir Sheriff* \\ Melmaruvathur Adhiparasakthi Institute of Medical Sciences and Research, Tamil Nadu, India
}

Submission: February 10, 2017; Published: February 27, 2017

*Corresponding author: Dhastagir Sheriff, Institute of Medical Sciences and Research, Melmaruvathur, Tamil Nadu, India, Email: drdsheriff@gmail.com

\section{Perspective}

White adipose tissue is an active endocrine gland communicates with the brain and the peripheral tissue including pancreatic beta cell through adipocytokines [1]. Examples of adipokines are; acylation stimulating protein (ASP), adiponectin, adipsin, angiotensinogen, bone morphogenic protein (BMP), estrogen, insulin-like growth factor-1 (IGF-1), various IGF binding proteins, interleukins (ILs), leptin, monocyte chemoattractant protein 1 (MCP-1), plasminogen activator I (PAI-1), resistin, TNF-alpha, transforming growth factorbeta (TGF-beta) and various prostaglandins [2-8] (Figure 1).

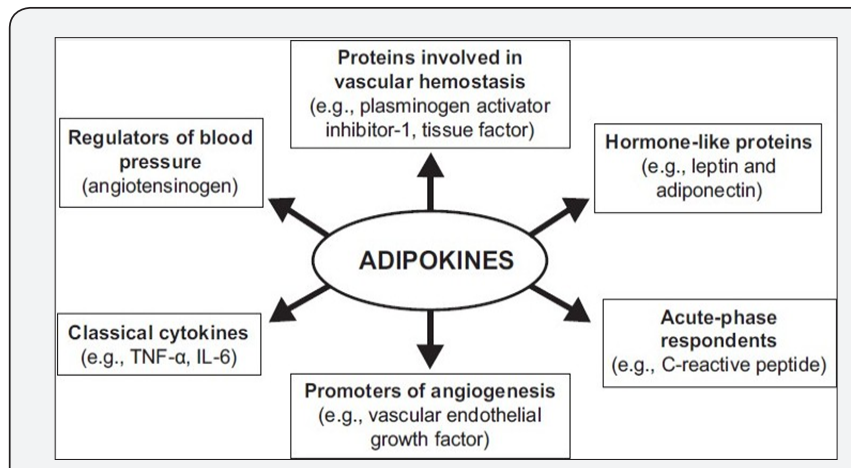

Figure 1: Adipokines and Body Processes.

Adipokines influence many physiological and metabolic processes, such as lipid metabolism, haemostasis, appetite and energy balance, immunity, insulin sensitivity, angiogenesis, inflammation and blood pressure regulation. Adiponectin and leptin are the most studied adipocytokines. Over $90 \%$ of adipokines are reported to be produced by the stromal-vascular cells. Different regions of white adipose tissue seem to secrete different adipokines $[9,10]$. For example, subcutaneous fat depot is reported to secrete leptin and visceral adipose tissue IL-6. Secretory products of visceral adipose tissue are reported to be six adipokines, three chemokines (growth-related oncogen factor, RANTES, macrophage inflammatory protein-1), one interleukin (IL-7), one tissue inhibitor of metalloproteinases (TIMP-1), and one growth factor (thrombopoietin)[11] It is also suggested that size of the adipocytes influence adipokine secretion. Hypertrophied adipocytes in obesity secrete less adiponectin and more in lean subjects with small sized adipocytes [12]. This could form the basis for the association of adipocyte size to obesity-related complications, such as insulin resistance and the increased risk for coronary heart disease [13] (Figure 2).

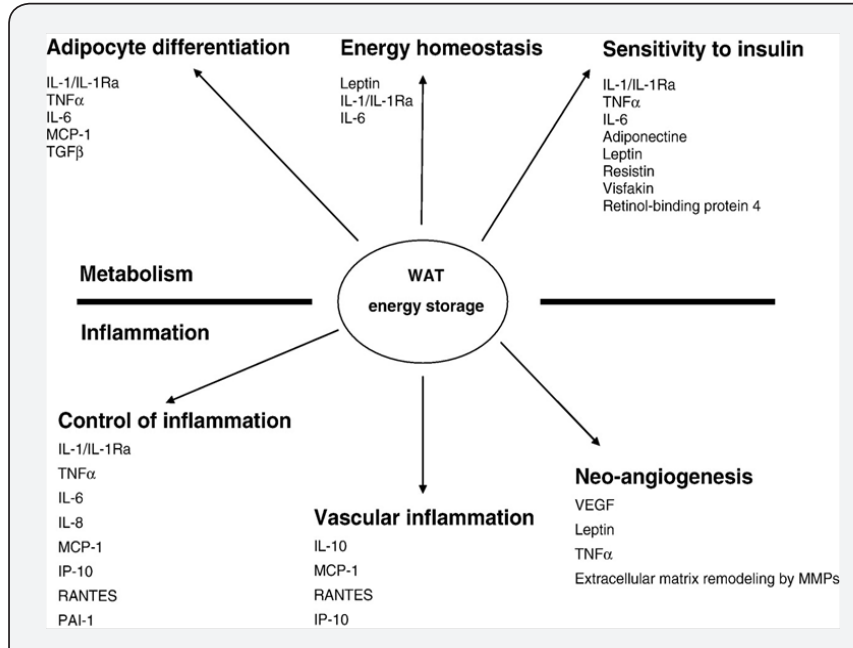

Figure 2: The Major functions of white Adipose Tissue.

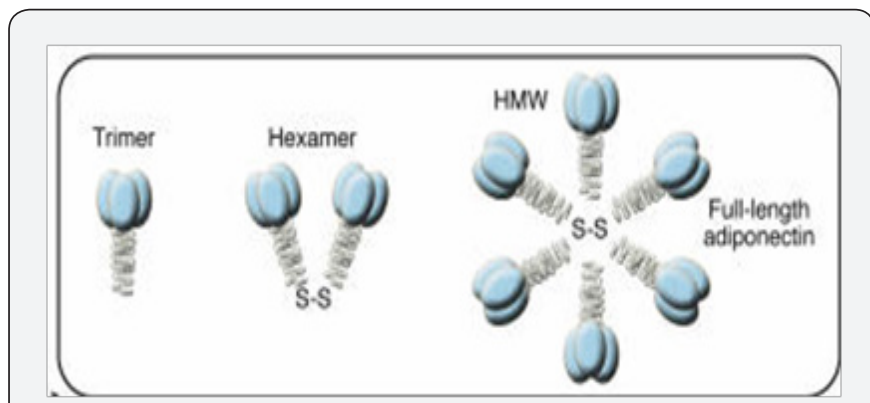

Figure 3: Different Forms of Adiponectin.

Of the major adipokines Adiponectin (APN) has a molecular weight of 30-kDA .It exists in many different forms. APN exists as a trimer, known as low molecular weight oligomers, a hexamer, 
which consist of two trimers linked by a disulphide bond known as middle-molecular weight adiponectin, and a high molecular weight (HMW) multimer [14-17]. The relative distribution of adiponectin multimers seems to differ between the adipose tissue and the circulation. The larger HMW forms is dominating in plasma, [5] whereas the presence of the globular fragment in human plasma has been questioned [6,7] (Figure 3). APN is considered to be an important modulator of insulin sensitivity [8] and dyslipidemia [9]. AP is reported to be an anti-inflammatory marker which is shown to have an inverse relation with proinflammatory markers like fibrinogen, intracellular adhesion molecule-1, Eselectin, and C-reactive protein [10,11]. APN though structurally related to TNF $\alpha$, increases insulin sensitivity particularly in the liver, promotes beta cell function and survival [12]. AP is shown to bind with its receptors in beta cells and may augment glucose induced insulin secretion [13]. It is considered to be a powerful anti-apoptotic molecule possibly through the activation of kinases which promote beta cell survival along with reducing the levels of ceramide and increasing the sphingosine1-phosphate, one of the key anti- apoptotic metabolite [14]. APN is also reported to have a protective effect on coronary artery disease (CAD) evidenced by prospective studies indicating that higher adiponectin is associated with a decreased risk CAD in non diabetic subjects [15] type I diabetic subjects [16], type 2 diabetic men [17] and in end-stage renal disease patients [18].

APN appears to play an important role in the pathogenesis of type 2 diabetes. T2DM patients are reported to have reduced serum levels of APN compared to control subjects [19-21]. It is also observed that higher APN levels are associated with better lipid and glycemiccontrol inT2DM subjects [22,23]. Therefore it is assumed that APN could be a marker of insulin resistance and T2DM [24]. Adiponectin is widely regarded as an anti-atherogenic, antioxidant and anti-inflammatory molecule. However, adiponectin concentration is paradoxically increased in individuals with type 1 diabetes, in whom it is positively associated with adverse clinical outcomes [23]. There is now considerable body of evidence to suggest that there is link between visceral fat and CHD. That is why these molecules are collectively named as 'adipocytokines.' It is also known that 'visceral fat syndrome' may cause dysregulation of adipocytokines and clustering of other factors. A direct link has been established between visceral fat and CHD. It was named collectively as adipocyte-derived molecules as 'adipocytokines'. The 'visceral fat syndrome' accelerates atherosclerosis due to the dysregulation of adipocytokines and clustering of other coronary risk factors [25].

Circulating adiponectin is shown to accumulate where endothelial barrier is damaged, and has protective effects against almost the whole process of atherosclerosis [18].Therefore adiponectin and other adipokines do play a vital role in the metabolic processes of the body. APN's role in insulin action and insulin sensitivity needs more studies to bring out the beneficial effects of APN and its associated adipokines.

\section{References}

1. Trayhurn P (2005) The biology of obesity. Proc Nutr Soc 64(1): 31-8.

2. Flier JS, Cook KS, Usher P, Spiegelman BM (1987) Severely impaired adipsin expression in genetic and acquired obesity. Science 237 (4813): 405-458.

3. Sartipy P, Loskutoff DJ (2003) Monocyte chemoattractant protein 1 in obesity and insulin resistance. Proc Natl Acad Sci USA 100(12): 72657270 .

4. Bruun JM, Pedersen SB, Richelsen B (2001) Regulation of interleukin 8 production and gene expression in human adipose tissue in vitro. J Clin Endocrinol Metab 86(3): 1267-1273.

5. Fried SK, Bunkin DA, Greenberg AS (1998) Omental and subcutaneous adipose tissues of obese subjects release interleukin-6: depot difference and regulation by glucocorticoid. J Clin Endocrinol Metab 83(3): 847-50.

6. Hotamisligil GS, Shargill, NS, Spiegelman BM (1993) Adipose expression of tumor necrosis factor-alpha: direct role in obesity-linked insulin resistance. Science 259(5091): 87-91.

7. Karlsson C, Lindell K, Ottosson M, Sjöström L, Carlsson B, et al. (1998) Human adipose tissue expresses angiotensinogen and enzymes required for its conversion to angiotensin II. J Clin Endocrinol Metab 83(11): 3925-3929.

8. Samad F, Yamamoto K, Loskutoff DJ (1996) Distribution and regulation of plasminogen activator inhibitor-1 in murine adipose tissue in vivo. Induction by tumor necrosis factor-alpha and lipopolysaccharide. J Clin Invest 97(1): 37-46.

9. Maury E, Ehala-Aleksejev K, Guiot Y, Detry R, Vandenhooft A, et al. (2007) Adipokines oversecreted by omental adipose tissue in human obesity. Am J Physiol Endocrinol Metab 293(3): E656-E665.

10. Fu Y, Luo N, Klein RL, Garvey WT (2005) Adiponectin promotes adipocyte differentiation, insulin sensitivity, and lipid accumulation. J Lipid Res 46(7): 1369-1379.

11. Juhan-Vague I, Alessi MC, Morange, PE (2000) Hypofibrinolysis and increased PAI-1 are linked to atherothrombosis via insulin resistance and obesity. Ann Med 32 Suppl 1: 78-84.

12. Turer AT, Scherer PE (2012) Adiponectin: mechanistic insights and clinical implications. Diabetologia 55(9): 2319-2326.

13. Wijesekara N, Krishnamurthy M, Bhattacharjee A, Suhail A, Sweeney G, et al. (2010) Adiponectin-induced ERK and Akt phosphorylation protects against pancreatic beta cell apoptosis and increases insulin gene expression and secretion. J Biol Chem 285(44): 33623-33631.

14. Holland WL, Miller RA, Wang ZV, Sun K, Barth BM, et al. (2011) Receptor-mediated activation of ceramidase activity initiates the pleiotropic actions of adiponectin. Nat Med 17(1): 55-63.

15. Pischon T, Girman CJ, Hotamisligil GS, Rifai N, Hu FB, et al. (2004) Plasma adiponectin levels and risk of myocardial infarction in men. JAMA 291(14): 1730-1737.

16. Costacou T, Zgibor JC, Evans RW, Otvos J, Lopes-Virella MF, et al. (2005) The prospective association between adiponectin and coronary artery disease among individuals with type 1 diabetes: the Pittsburgh Epidemiology of Diabetes Complications Study. Diabetologia 48(1): 4148.

17. Qi L, Rimm E, Liu S, Rifai N, Hu FB (2005) Dietary glycemic index, glycemic load, cereal fiber, and plasma adiponectin concentration in diabetic men. Diabetes Care 28(5): 1022-1028.

18. Zoccali C, Mallamaci F, Tripepi G, Benedetto FA, Cutrupi S, et al. (2002) Adiponectin, metabolic risk factors, and cardiovascular events among patients with end-stage renal disease. J Am Soc Nephrol 13(1): 134141. 
19. Statnick MA, Beavers LS, Conner LJ, Corominola H, Johnson D, et al (2000) Decreased expression of apM1 in omental and subcutaneous adipose tissue of humans with type 2 diabetes. Int J Exp Diabetes Res 1(2): 81-88

20. Hotta K, Funahashi T, Arita Y, Takahashi M, Matsuda M, et al. (2000) Plasma concentrations of a novel, adipose-specific protein, adiponectin in type 2 diabetic patients. Arterioscler Thromb Vasc Biol 20(6): 15951599.

21. Yenicesu M, Yilmaz MI, Caglar K, Sonmez A, Eyileten T, et al. (2005) Adiponectin level is reduced and inversely correlated with the degree of proteinuria in type 2 diabetic patients. Clin Nephrol 64(1):12-19.

22. Schulze MB, Rimm EB, Shai I, Rifai N, Hu FB (2004) Relationship between adiponectin and glycemic control, blood lipids, and inflammatory markers in men with type 2 diabetes. Diabetes Care 27(7): 1680-1687.
23. Forsblom C, Thomas MC, Moran J, Saraheimo M, Thorn L, et al. (2011) Serum adiponectin concentration is a positive predictor of all-cause and cardiovascular mortality in type 1 diabetes. J Intern Med 270(4): 346-355.

24. Lindsay RS, Resnick HE, Zhu J, Tun ML, Howard BV, et al. (2005) Adiponectin and coronary heart disease: the Strong Heart Study. Arterioscler Thromb Vasc Biol 25(3): e15-e16.

25.Zhaoxia Wang, Tomohiro Nakayama (2010) Inflammation, a Link between Obesity and Cardiovascular Disease. Mediators Inflamm 2010: 535918.

\section{Your next submission with Juniper Publishers will reach you the below assets}

- Quality Editorial service

- Swift Peer Review

- Reprints availability

- E-prints Service

- Manuscript Podcast for convenient understanding

- Global attainment for your research

- Manuscript accessibility in different formats

( Pdf, E-pub, Full Text, Audio)

- Unceasing customer service

Track the below URL for one-step submission https://juniperpublishers.com/online-submission.php 